\title{
The BOR in the Journal Citation Reports: An achievement by all of us!
}

Sigmar de Mello Rode Executive Editor
W hen the new Publishing Commission of the Brazilian Oral Research (BOR) took office, one of our concerns was to create a new, more up-to-date graphic design for the Journal. Our greatest endeavor, however, was to ensure correct indexation and citation of the BOR in the pertinent databases.

When researching the BOR in PUBMED, we found the title Pesquisa Odontológica Brasileira (POB). As of 2004, however, the POB changed its name permanently to Brazilian Oral Research, and the title POB remained on the journal's cover in finer print (only as a statement of its origin), leading relevant indexation databases - and even some authors - to assume the name had not changed and prompting them to continue working with the title POB.

Following the graphic makeover, effective as of Volume 21, we removed the entire POB title from the cover. We then wrote a letter to MEDLINE's Executive Editor, Sheldon Kotzin, who understood our concern and determined that BOR's citation would be changed in 2007. He further committed to gradually correcting the former citation of the Journal previous to 2007. Similar letters are also being forwarded to CNPq, CAPES and SCIELO, so as to correct this oversight definitively.

Authors that submit articles to the BOR can and should aid in this effort by registering their scientific production in the LATTES Platform and in DATACAPES using BOR's proper name and ISSN, so that our journal may also be correctly indexed in these databases.

We now have a new goal: to achieve indexation of the BOR at Thomson Scientific, which is responsible for the Journal Citation Reports (JCR) and for the Institute for Scientific Information (ISI). This will allow the BOR to be ranked as Qualis B - International in the CAPES journal ranking system.

In order to do so, two conditions need to be satisfied in addition to providing the pertinent documentation. First, the "international diversity geographic representation" of authors and citations must be obtained. Toward this end, a comprehensive effort to publicize BOR is being made to present the journal to the international community, aiming at boosting international participation in the journal. In fact, the effort is already producing results: we are presently receiving contributions from South America and North America.

The second condition requires the participation and strong support of all SBPqO members and authors of scientific articles: papers published in the BOR must be cited in articles published in the 49 scientific journals in the field of dentistry (and others) that are indexed in the JCR. They are presented in the table on the next page.

Furthermore, when submitting new articles for publication in the BOR, we must not forget to cite any earlier articles published in the selfsame BOR.

We must trust in the effective results of this effort to bring benefits to the entire Brazilian scientific community, especially to the dental community, as we will be the first Brazilian journal in the JCR.

The application for inclusion can be submitted only once every two years, and we intend to do so in 2008. We count on the participation of everyone toward achieving this greater goal, and contributing toward builduing a higher level of Brazilian dentistry.

More changes are yet to come. 
Editorial

Table - Journals from the Dentistry, Oral Surgery \& Medicine categories (2006 JCR Science Edition - http://admin.isiknowledge.com/JCR/JCR).

\begin{tabular}{|c|c|c|c|c|}
\hline Rank & Abbreviated Journal Title (linked to journal information) & ISSN & $\begin{array}{l}\text { Impact } \\
\text { Factor }\end{array}$ & Articles \\
\hline 1 & Acta Odontologica Scandinavica & $0001-6357$ & 1.017 & 60 \\
\hline 2 & American Journal of Dentistry & $0894-8275$ & 1.027 & 76 \\
\hline 3 & American Journal of Orthodontics and Dentofacial Orthopedics & 0889-5406 & 0.968 & 194 \\
\hline 4 & Angle Orthodontist & 0003-3219 & 0.777 & 162 \\
\hline 5 & Archives of Oral Biology & 0003-9969 & 1.655 & 142 \\
\hline 6 & Australian Dental Journal & $0045-0421$ & 0.568 & 56 \\
\hline 7 & British Dental Journal & $0007-0610$ & 0.848 & 121 \\
\hline 8 & British Journal of Oral \& Maxillofacial Surgery & $0266-4356$ & 0.654 & 116 \\
\hline 9 & Caries Research & $0008-6568$ & 2.304 & 79 \\
\hline 10 & Cleft Palate-Craniofacial Journal & $1055-6656$ & 0.724 & 108 \\
\hline 11 & Cleft Palate-Craniofacial Journal & $0905-7161$ & 2.497 & 114 \\
\hline 12 & Community Dentistry and Oral Epidemiology & $0301-5661$ & 1.870 & 50 \\
\hline 13 & Cranio-the Journal of Craniomandibular Practice & $0886-9634$ & 0.603 & 37 \\
\hline 14 & Critical Reviews in Oral Biology \& Medicine & $1045-4411$ & 6.000 & 0 \\
\hline 15 & Dental Materials & $0109-5641$ & 2.381 & 148 \\
\hline 16 & Dental Traumatology & $1600-4469$ & 0.744 & 64 \\
\hline 17 & Dentomaxillofacial Radiology & $0250-832 X$ & 0.821 & 87 \\
\hline 18 & European Journal of Oral Sciences & 0909-8836 & 1.747 & 132 \\
\hline 19 & European Journal of Orthodontics & $0141-5387$ & 0.621 & 91 \\
\hline 20 & International Dental Journal & $0020-6539$ & 0.364 & 52 \\
\hline 21 & International Endodontic Journal & 0143-2885 & 1.429 & 115 \\
\hline 22 & International Journal of Oral \& Maxillofacial Implants & $0882-2786$ & 1.705 & 102 \\
\hline 23 & International Journal of Oral and Maxillofacial Surgery & $0901-5027$ & 1.212 & 193 \\
\hline 24 & International Journal of Periodontics \& Restorative Dentistry & $0198-7569$ & 0.898 & 56 \\
\hline 25 & International Journal of Prosthodontics & $0893-2174$ & 1.660 & 97 \\
\hline 26 & Journal of Adhesive Dentistry & $1461-5185$ & 1.313 & 54 \\
\hline 27 & Journal of the American Dental Association & $0002-8177$ & 1.162 & 154 \\
\hline 28 & Journal of Clinical Periodontology & 0303-6979 & 2.380 & 125 \\
\hline 29 & Journal of Cranio-maxillofacial Surgery & 1010-5182 & 1.171 & 92 \\
\hline 30 & Journal of Dentistry & $0300-5712$ & 1.702 & 107 \\
\hline 31 & Journal of Dental Research & $0022-0345$ & 3.475 & 177 \\
\hline 32 & journal of Endodontics & 0099-2399 & 3.077 & 208 \\
\hline 33 & journal of Oral and Maxillofacial Surgery & $0278-2391$ & 1.252 & 274 \\
\hline 34 & journal of Oral Pathology \& Medicine & 0904-2512 & 1.530 & 106 \\
\hline 35 & Journal of Oral Rehabilitation & $0305-182 X$ & 1.044 & 124 \\
\hline 36 & Journal of Orofacial Pain & $1064-6655$ & 1.889 & 29 \\
\hline 37 & Journal of Periodontal Research & 0022-3484 & 2.472 & 78 \\
\hline 38 & Journal of Periodontology & 0022-3492 & 1.703 & 248 \\
\hline 39 & Journal of Prosthetic Dentistry & 0022-3913 & 0.879 & 148 \\
\hline 40 & Journal of Public Health Dentistry & $0022-4006$ & 0.805 & 49 \\
\hline 41 & Operative Dentistry & $0361-7734$ & 1.449 & 103 \\
\hline 42 & Oral Diseases & $1354-523 X$ & 1.464 & 84 \\
\hline 43 & Oral Microbiology and Immunology & $0902-0055$ & 2.089 & 66 \\
\hline 44 & Oral Oncology & $1368-8375$ & 2.103 & 130 \\
\hline 45 & $\begin{array}{l}\text { Oral Surgery Oral Medicine Oral Pathology } \\
\text { Oral Radiology and Endodontics }\end{array}$ & $1079-2104$ & 1.221 & 227 \\
\hline 46 & Pediatric Dentistry & $0164-1263$ & 0.766 & 71 \\
\hline 47 & Periodontology 2000 & $0906-6713$ & 2.800 & 36 \\
\hline 48 & Quintessence international & 0033-6572 & 0.606 & 91 \\
\hline 49 & Swedish Dental Journal & $0347-9994$ & 0.684 & 15 \\
\hline
\end{tabular}

